\title{
Utilization of persimmon powder in gluten-free cakes and determination of their physical, chemical, functional and sensory properties
}

\author{
Nazlıcan YEŞİLKANAT ${ }^{1 *}$, Nazlı SAVLAK ${ }^{1}$ (D)
}

\begin{abstract}
Reaching nutritious snack foods to consume outside, especially during socialization, is of great importance for celiac people. This study investigates the effects of partial substitution of sugar with persimmon powder $(0 \%, 20 \%, 40 \%, 60 \%$ and $80 \%)$ as a source of sugar, in gluten-free cake formulation. Specific volume and density ranged between $1.48-2.04 \mathrm{~mL} / \mathrm{g}$ and $4.89-6.54 \mathrm{~g} / \mathrm{mL}$ in persimmon powder substituted cakes, respectively, whereas it was $2.08 \mathrm{~mL} / \mathrm{g}$ and $5.06 \mathrm{~g} / \mathrm{mL}$ in control cake. Substitution of sugar with 20 and $40 \%$ persimmon powder resulted in statistically comparable cakes with control in terms of specific volume and density. Springiness, cohesiveness and resilience decreased; hardness and chewiness increased by increasing persimmon powder substitution. 20\% persimmon powder substituted gluten-free cake was statistically similar to control cake in terms of hardness. Persimmon inclusion lead to enriched cakes with significantly higher total phenolic content (up to 304.2\%), ferric reducing antioxidant power (up to $384.4 \%$ ) and radical scavenging activity (up to $264.3 \%$ ). Enriched gluten-free cakes with increased $\mathrm{K}$, antioxidant activity, total phenolic content as well as favorable sensorial and physical properties were achieved by 20 and $40 \%$ persimmon powder substitution. This study can help socialization of celiac people outside their houses by providing nutritious cakes.
\end{abstract}

Keywords: persimmon; gluten-free; cake; antioxidant activity; sensory analysis.

Practical Application: This study enabled enriched cakes with acceptable sensory properties for celiac people.

\section{Introduction}

Nutrition of celiac people is heavily based on starch-rich formulations which do not offer a well-balanced diet. In recent years, contributing to the nutrition of celiac people by adding functional ingredients to the gluten-free food formulations is on rise. Reaching nutritious snack foods to consume outside, especially during socialization, is of great importance for celiac people. Cake is one of the favorite snack food due to easy preparation and a variety of ingredients.

Being gluten-free and highly nutritious, persimmon can be used in gluten-free formulations. It is rich in primary metabolites (especially sugars), a good source of antioxidants, carotenoids and polyphenols, and an important fruit in terms of bioactive components (Ittah, 1993; Suzuki et al., 2005; Gu et al., 2008; Veberic et al., 2010; Giordani et al., 2011). Secondary metabolites are bioactive components that have a positive effect on human health. In the food industry, bioactive ingredients are used as additives, functional food ingredients or nutritional supplements (Güven \& Gürsul, 2014). Considering the general composition of persimmon, it is known that the fruit is very rich in ascorbic acid and phenolic compounds, and this ensures high antioxidant activity of the fruit. In addition to vitamins $\mathrm{A}$ and $\mathrm{E}$, ripe fruit has an important place among functional products due to its rich carbohydrate and tannin content as well as high dietary fiber (Doymaz, 2012).

Studies on persimmon reveal the functional features of the fruit in detail. The amount of soluble polyphenol of the fruit is reported between $1.3 \mathrm{mg} \mathrm{GAE} / 100 \mathrm{~g}$ fresh fruit and $1480 \mathrm{mg}$ $\mathrm{GAE} / 100 \mathrm{~g}$ fresh fruit, depending on the variety (Giordani et al., 2011). Karhan et al. (2003) determined the change in main carotenoid compound and L-ascorbic acid of Fuyu and Hachiya varieties by HPLC during the ripening period of persimmon. Phenolic compounds showed a significant decrease during ripening especially in astringent Hachiya variety. While these values were highest in Fuyu $(84.7 \mathrm{mg} / \mathrm{kg})$, it decreased to $39.6 \mathrm{mg} / \mathrm{kg}$ at the end of ripening. Gorinstein et al. (1999) conducted a comparative study on total phenolic substance, gallic acid, soluble and total dietary fiber content of tropical fruits (pineapple, apple, rambutan, lichi, guava, mango, etc.) and persimmon. Persimmon had higher polyphenol, gallic acid, soluble and total dietary fiber content than other tropical fruits (unripe green mango, pineapple, apple, rambutan).

Studies on development of gluten free cake is studied extensively in the literature. Feng et al. (2019) prepared rice cake with naturally fermented rice flour. Türker et al. (2016) investigated the effect of green banana peel flour substitution on physical properties of gluten free cakes. Kırbaş et al. (2019) studied the effects of 5-15\% apple pomace powder, carrot and orange pomace powders on gluten free cake properties. However, studies on utilization of persimmon in development of enriched products is very limited. Abdallah et al. (2017) substituted sugar solution with persimmon puree at $33.3,50,66.6$ and $83.3 \%$ in wheat flour cupcake and reported sensorially acceptable cakes 
at $33.3 \%$ substitution ratio. Hong \& Kim (2005) investigated the effects of astringency persimmon paste substitution (0-20\%) on quality characteristics of rice cakes and obtained sensorially acceptable cakes. Other studies include development of ice-cream (Karaman et al., 2014) and yogurt (Arslan \& Bayrakci, 2016).

Persimmon is known to have high sugar content as well as bioactive ingredients. Sugar content $(12.5 \mathrm{~g} / 100 \mathrm{~g})$ are higher in persimmon than other extensively consumed fruits such as apple, peach, pear and orange (Piretti, 1991). The fruit is at the potential of an ingredient that helps to reduce the amount of sugar taken with a daily diet. To the best of authors' knowledge, there is no study on utilization of persimmon powder as a sugar substitute in gluten-free cakes. Physical (volume, weight, specific volume, density, height, color, texture profile analysis) chemical (moisture, ash, protein, oil, sugar, $\mathrm{pH}$, water activity), functional (dietary fiber, mineral substance, antioxidant activity, phenolic substance amount) and sensory properties of rice flour gluten-free cakes developed by using 20\%, 40\%, 60\% and $80 \%$ of Hachiya variety as a sugar substitute in cake production were determined and compared with control cake.

\section{Materials and methods}

\subsection{Materials}

Unripe persimmon cv. Hachiya (D. kaki L.) fruits were supplied from Manisa, Saruhanl fruits wholesale market in October-November 2018. Rice flour, milk, eggs, sugar, sunflower oil, and flaking powder to be used in cake production were obtained from a local market, among the brands listed as glutenfree on the website www.colyak.org.tr. Xanthan gum, guar gum, HPMC, polydextrose were obtained from Smart Kimya.

\subsection{Methods}

\section{Production of Hachiya powder}

The persimmons brought to the laboratory were washed, cut into two, and then the leaves and seeds were separated and sliced. Slices were soaked in citric acid solution ( $1 \mathrm{~g} / \mathrm{L})$ for 1 minute, dried in the tray dryer at $65 \mathrm{C}$ to $6-8 \%$ humidity, then ground in a blade grinder (Retsch Grindomix GM 200, Germany) at $6500 \mathrm{rpm}$ for $1 \mathrm{~min}$. Hachiya powder obtained was stored in airtight containers to be used in cake production.

\section{Gluten-free cake production}

Gluten-free cakes were baked according to the method specified in Gularte et al. (2012) with some modifications. Control cake included rice flour (150 g), milk (112.5 g), egg (93.75 g), sugar (150 g), xanthan gum (0.95 g), guar gum (0.95) g), hydroxy propyl methyl cellulose (HPMC) (0.95 g), sunflower oil (56.25 g) and baking powder (5.625 g). Amounts of all the ingredients in the cake formulation had become definite after preliminary trials. Hachiya powder substituted sugar in the gluten-free cake formulation by $0 \%$ (control), $20 \%, 40 \%$ and $60 \%$ and $80 \%$. To prevent cross contamination during production, the bench was wiped with ethanol and the same materials were always used. For cake production; eggs and sugar was mixed for 4 minutes in the $6^{\text {th }}$ cycle Kitchenaid Artisan (Model 5KSM150),
6 minutes in the $8^{\text {th }}$ cycle, and all the ingredients were added and mixed for 2 minutes in the $1^{\text {st }}$ cycle. Cakes were baked at $170{ }^{\circ} \mathrm{C}$ for 40 minutes and were left to cool followed by storing in airtight glass containers and physical analysis were carried out 24 hours after baking. Cakes were also stored at $-18^{\circ} \mathrm{C}$ for further chemical and functional analysis.

\section{Physical properties of cakes}

Volume, specific volume, density, height

Cakes were weighed in grams (g) using analytical balance. Volume, specific volume, density and heights of the cakes were determined according to Geisslitz et al. (2018) 20-24 hours after baking according to the laser scanning principle using the VolScan Profiler (Stable Micro Systems, Godalming, England) located in the Grain Technology laboratory of the Ege University, Food Engineering Department.

\section{Baking loss}

Baking loss of gluten-free cakes was calculated according to Ho et al. (2013) by weighing the dough weight (DW) and cake weight (CW) using the following Formula 1.

$$
\text { Baking loss : }[(D W-C W) / D W \times 100]
$$

\section{Color profile}

Color of UBF samples were measured by a CR-5 Konica Minolta Chroma Meter (Osaka, Japan) using CIE LAB colour scale with the parameters $L^{\star} a^{\star} b^{\star}$. Mean value of six color measurements were recorded.

\section{Texture profile analysis}

Texture Profile Analysis (TPA) of cake samples was carried out using a TA-XT Plus Texture Analyzer (Stable Micro Systems, Godalming, England) equipped with a $5 \mathrm{~kg}$ load cell and $36 \mathrm{~mm}$ cylinder probe. Texture profile analysis involved compressing the sample twice and quantifying the mechanical properties, such as hardness, springiness, cohesiveness, chewiness and resilience. Texture profile analysis was carried out under following conditions: pre-test speed $=0.8 \mathrm{~mm} / \mathrm{s}$; test speed $=1 \mathrm{~mm} / \mathrm{s}$; post-test speed= $5 \mathrm{~mm} / \mathrm{s}$; strain $=30 \% .25 \mathrm{~mm}$ thick cake samples were cut using a hollow circular cylinder at a diameter of $25 \mathrm{~mm}$ in order to obtain samples with $25 \mathrm{~mm}$ height and $25 \mathrm{~mm}$ diameter. Mean value of ten measurements were reported.

\section{Chemical properties of cakes}

Gluten content

Randomly selected cakes were extracted with the Cocktail (patented) (Art. No. R7006, R7016, official R5-Mendez method) and the amount of gluten was determined according to AACC Method (38-50.01) by the sandwich kit (Ridascreen ${ }^{\circledR}$ Gliadin) (American Association of Cereal Chemists, 2010). Elisa (BioTek ${ }^{\circledR}$, ELx800 Absorbance Microplate Reader, USA). Ingredients with less than 20 ppm gliadin content were expressed as gluten-free, according to Turkish Food Codex Regulation "Rescript on Foods 
Suitable for Individuals with Gluten Intolerance" (Turkey, 2012). Gloves were used before and during the analysis and surfaces such as bench, scales, spatula, plastic/glass tubes, grinder etc. were wiped with ethanol (40\%). Results were measured in ppm gliadin in RIDA ${ }^{\circledR}$ SOFT Win (Version 1.81).

\section{Proximate composition}

Moisture (934.01) and ash (923.03) and total dietary fibre (992.16) content of the samples were determined according to AOAC Methods (Association of Official Analytical Chemists, 2000). Dietary fiber content of gluten-free cakes were determined according to AOAC Method 991.43 (Association of Official Analytical Chemists, 2003). In this method, sample was hydrolyzed with amylase followed by treatment with protease and amyloglucosidase. After removing protein and starch, soluble fiber fraction was precipitated with $78 \%$ ethanol. The residue was filtered, washed with ethanol and acetone, followed by drying.

\section{Mineral matter}

Cake samples $(1 \mathrm{~g})$ were treated to microwave assisted wet ashing with $10 \mathrm{~mL}$ of nitric acid (65\%) by CEM MARS 6 model microwave. Microwave digestion conditions were as follows; $15 \mathrm{~min}$. ramp time, $15 \mathrm{~min}$. hold time, $200^{\circ} \mathrm{C}$ and 400-1800 W. Digested samples were centrifuged at $4000 \mathrm{rpm}$ for 10 minutes. The mineral matter composition of the samples was then determined by Optima 8000 ICP-OES (Perkin Elmer, USA). Mineral composition ( $\mathrm{Fe}, \mathrm{Ca}, \mathrm{P}, \mathrm{Zn}, \mathrm{K}, \mathrm{Mg}$ ) of the samples was determined according to NMKL 161 standard procedure (Nordic Committee on Food Analysis, 1998). Inductively coupled plasma-optical emission spectrometry (ICPOES) conditions were: ICP RF power, $300 \mathrm{~W}$.; plasma gas; $17 \mathrm{~L} / \mathrm{min}$; auxiliary gas, $0.2 \mathrm{~L} / \mathrm{min}$; and nebulizer gas, $0.8 \mathrm{~L} / \mathrm{min}$.

\section{Antioxidant activity and total phenolic content}

\section{Extraction}

Extraction of cake samples for antioxidant analysis were carried out according to Aksoylu et al. (2015). Cakes were defatted by adding $100 \mathrm{~mL}$ of diethylether on $50 \mathrm{~g}$ ground cake sample followed by standing for 18 hours. Defatted cake samples were then dried on a coarse filter paper for 24 hours at room temperature. $5 \mathrm{~g}$ defatted cake was mixed with $25 \mathrm{~mL}$ methanol: water mixture (v/v, 1:1) incubated at $50^{\circ} \mathrm{C}$ for $15 \mathrm{~min}$ in oscillating water bath. The mixture was then centrifugated at $4000 \mathrm{rpm}$ and $20^{\circ} \mathrm{C}$ for $10 \mathrm{~min}$. Supernatant was transferred into a $100 \mathrm{~mL}$ volumetric flask. The same procedure was applied to the residue two times more. The volume of the flask was completed to $100 \mathrm{~mL}$ by methanol:water mixture (v/v, 1:1). The content of the volumetric flask was filtered through Whatman No: 1 and $0.45 \mu \mathrm{m}$ respectively and kept in $50 \mathrm{~mL}$ volumetric flasks at $-86^{\circ} \mathrm{C}$ before antioxidant analyses were carried out.

\section{DPPH assay}

DPPH (1,1-diphenyl-2-picrylhydrazyl radical scavenging activity) of cake samples was determined according to Brand-
Williams et al. (1995) as detailed in Savlak et al. (2016). A Trolox standard serial $(25,50,100,150,200,300,400$ and $500 \mu \mathrm{M})$ was prepared for DPPH calculation. Slope of the sample regression equation was divided by the slope of Trolox regression equation $\left(y=0.0828 x, R^{2}=0.9975\right)$. Results were stated as \% inhibition and $\mathrm{mg}$ Trolox Equivalent/g oil free dry matter.

\section{FRAP assay}

FRAP (Ferric reducing antioxidant power) assay was carried out according to Liu et al. (2008) and Wang et al. (2012) with some modifications. In brief, $3 \mathrm{~mL}$ FRAP reagent was involved in $50 \mu \mathrm{L}$ extract and let to stand at $37^{\circ} \mathrm{C}$ for 30 minutes. Absorbance at $593 \mathrm{~nm}$ was measured (Shimadzu UV-601, Japan) against distilled water blank. Calibration curve was drawn by using varying concentrations of $\mathrm{FeSO}_{4} \cdot 7 \mathrm{H}_{2} \mathrm{O}(0.05-2 \mathrm{mM} / \mathrm{L})$ ( $\left.\mathrm{y}=0.8175 \mathrm{x}-0.0376, \mathrm{R}^{2}=0.9998\right)$. Results were stated as $\mathrm{mmol}$ of Fe (II)/g oil free dry matter.

Total phenolic compounds

Method of Singleton \& Rossi (1965) was used in order to determine total polyphenol content of samples. $100 \mu \mathrm{L}$ extract was involved in $2.5 \mathrm{~mL}$ Folin-Ciocalteu reagent $(10 \%, \mathrm{v} / \mathrm{v})$, vortexed for 15 seconds, kept in dark for 5 minutes. $5 \mathrm{~mL}$ $\mathrm{NaHCO} 3$ solution $(7.5 \%, \mathrm{w} / \mathrm{v})$ was added and the mixture was kept in dark for 60 minutes at room temperature. Gallic acid standards $(2.5-20 \mu \mathrm{g} / 100 \mu \mathrm{L})$ were used to draw calibration curve. Absorbance of cakes and the standards were recorded at $760 \mathrm{~nm}$ by using a Shimadzu UV-601 (Japan) spectrofotometer. Lineer regression equation obtained from gallic acid calibration curve $\left(y=0.0134 \mathrm{x}-0.0555, \mathrm{R}^{2}=0.9996\right)$ was used to determine total polyphenol content of cake samples as $\mathrm{mg} \mathrm{GAE/g}$ oil free dry matter.

\section{Sensory evaluation of cakes}

Persimmon powder substituted cakes were evaluated using a 7-Point Hedonic Scale with the participation of 25 panelists (15 females, 5 males; aged 24-57), academic staff of Manisa Celal Bayar University Food Engineering Department. Sensory analysis was performed at 14.30 in the afternoon. Panelists were provided with drinking water to clean their mouth during sensory panel. They were asked to evaluate the randomly coded cakes between 1-7 points (1: disliked extremely, 2: disliked, 3: disliked slightly, 4: neither liked nor disliked, 5: liked slightly, 6: liked and 7: liked extremely) in terms of crust color, interior cake color, odor, flavor, hardness, chewiness, mouthfeel and overall acceptability (Lazaridou et al., 2007; Sabanis et al., 2009). The cakes with an overall acceptability score greater than 4.00 were regarded as acceptable in terms of sensory evaluation parameters.

\section{Statistical analysis}

All measurements and analysis were carried in three replicates and at least three parallels. Color profile and texture profile analysis were shown as mean \pm standard deviations in the tables. The one-way analysis of variance (ANOVA) and the Duncan's Multiple Comparison Test $(\mathrm{p}<0.05)$ were used to determine least significant differences among the mean values of physical and 
functional properties of cakes for different permission powder substitution ranges. Data were analyzed using the computer Statistical Analysis Systems version 8.2 (1999-2001) software, SAS Institue Inc., Cary NC (Statistical Analytical Systems, 2001).

\section{Results and discussion}

\subsection{Physical properties of cakes}

Physical properties of control and Hachiya powder substituted cakes were presented in Table 1. The change of the height and volume with Hachiya powder substitution ratio was statistically significant ( $\mathrm{p}<0.05) .20-60 \%$ Hachiya powder substituted cakes (HPSC) were not different from control cake in terms of height and volume while $80 \%$ HPSC had lower height and volume values. Spesific volume decreased with increasing Hachiya powder substitution ratio and the effect of Hachiya powder ratio on specific volume of cakes were statistically significant ( $\mathrm{p}<0.05) .20 \%$ HPSC was not different from control cake, whereas $40 \%$ and $60 \%$ Hachiya powder substitution resulted in cakes with medium spesific volume. However, substitution of sugar with $80 \%$ Hachiya powder caused detrimental effect on spesific volume of cakes. Sugar affects the physical structure of baked products by organizing gelatinization of starch. Delay in starch gelatinization during baking allows air bubbles to expand properly due to vapor pressure build up by carbon dioxide and water vapor before the cake sets (Kim \& Setser, 1992; Kim \& Walker, 1992). In addition, sugar in the cake formulation promotes good air incorporation leading to a more viscous and stable foam (Paton et al., 1981). So, high ratios of sugar replacement with Hachiya powder resulted in decreased cake volume.

In contrast, Al-Sayed \& Ahmed (2013) enriched cakes with melon and watermelon peels $(2.5 \%, 5 \%$ and $7 \%)$ and reported that increasing peel ratio resulted in increased volume and specific volume of the cakes. In the present study, volume increased slightly in 20\% HPSC followed by a sharp decrease in especially $60 \%$ and $80 \%$ HPSC. This may be due to the high rate of substitution in the present study. Persimmon is also a good source of dietary fibre. Thus, substitution of the fruit powder in low levels (20\%) lead to an increase in cake volume. Abdallah et al. (2017) conducted a study to investigate the impact of utilizing persimmon puree on some chemical, physical and sensory properties of cupcakes. Similar to our results, they pointed out that replacement of sugar solution with persimmon in wheat flour cakes in the range of 33.3-83.3\% first increased than decreased volume and spesific volume of cakes. Cupcake volume increased from $28 \mathrm{~cm}^{3}$ (control) to $69.7 \mathrm{~cm}^{3}$ in $33.3 \%$ persimmon substituted cakes and declined to $14.7 \mathrm{~cm}^{3}$ in 83.3\% persimmon substituted cakes. Similarly, specific volume followed the same trend with 2.79 and $0.45 \mathrm{~cm}^{3} / \mathrm{g}$ in 33.3 and $83.3 \%$ persimmon puree containing cupcakes, respectively, in comparison to control $\left(1.17 \mathrm{~cm}^{3} / \mathrm{g}\right)$.

The effect of the substitution rate on the density of cakes is statistically significant $(\mathrm{p}<0.05)$. Density of control, $20 \%$ and $40 \%$ Hachiya powder substituted cakes was similar whereas density of $60 \%$ and $80 \%$ HPSC substitute cakes was different from each other and control cake statistically $(\mathrm{p}<0.05)$. The change in baking loss of cakes by the replacement of sugar with Hachiya powder was statistically significant $(\mathrm{p}<0.05)$. It was determined that as the substitution rate increased, baking loss decreased and accordingly, the lowest baking loss was observed in the 80\% HPSC. This is a result of high water binding ability of dietary fibre in persimmon powder as well as lower water vapour release from the cake during baking.

\section{Cake color}

Table 2 presents interior color values of control and Hachiya powder substituted cakes. Carotenoids, consisting of $\beta$-carotene, $\gamma$-carotene and $\beta$-cryptoxanthin, are responsible from the characteristic reddish-orange color of persimmon fruit (Veberic et al., 2010). By Hachiya powder substitution, $L^{*}$ decreased and $a^{*}$ increased as expected $(\mathrm{p}<0.05)$ as expected. Due to reddish-orange color of the fruit, redness increased leading also a decline in $\mathrm{L}^{*}$ value. However, $20 \%$ and $80 \%$ HPSC did not differ from each other statistically ( $p>0.05)$. This is important in the way that high levels of fruit powder does not deteriorate cake color. On the other hand, $b^{*}$ values of cakes did not show a lineer decline or increment with Hachiya powder replacement. All samples except 20\% HPSC were similar with control cake in terms of $b^{*}$ value. Abdallah et al. (2017) also reported decreasing $\mathrm{L}^{*}$ value for persimmon puree included wheat flour cupcakes. However, persimmon fruit added to the formulation in that study did not lead to an increase in $\mathrm{a}^{\star}$ value, as it was in the form of puree instead of powder. In line with our findings, Hong \& Kim (2005) investigated the effects of astringency persimmon paste substitution (0-20\%) on quality characteristics of rice cake and stated that $\mathrm{L}$ value decreased and a value increased in enriched cakes.

Table 1. Physical properties of control and Hachiya powder substituted cakes

\begin{tabular}{|c|c|c|c|c|c|}
\hline \multirow{2}{*}{ Sample } & Height & Volume & Specific Volume & Density & Baking loss \\
\hline & $(\mathrm{mm})$ & $(\mathrm{mL})$ & $(\mathrm{mL} / \mathrm{g})$ & $(\mathrm{g} / \mathrm{mL})$ & $(\%)$ \\
\hline Control & $56.65 \pm 0.050^{\mathrm{ab}}$ & $906.10 \pm 29.570^{\mathrm{ab}}$ & $2.08 \pm 0.104^{\mathrm{a}}$ & $5.06 \pm 0.201^{\mathrm{c}}$ & $14.22 \pm 1.241^{\mathrm{a}}$ \\
\hline $20 \%$ HPSC & $61.12 \pm 3.848^{\mathrm{a}}$ & $945.98 \pm 21.791^{\mathrm{a}}$ & $2.04 \pm 0.025^{\mathrm{a}}$ & $4.89 \pm 0.040^{c}$ & $11.86 \pm 0.717^{\mathrm{b}}$ \\
\hline $40 \%$ HPSC & $53.13 \pm 2.657^{\mathrm{b}}$ & $868.88 \pm 56.969^{\mathrm{ab}}$ & $1.83 \pm 0.125^{\mathrm{b}}$ & $5.12 \pm 0.240^{c}$ & $9.75 \pm 0.612^{c}$ \\
\hline $60 \%$ HPSC & $51.18 \pm 2.789^{\mathrm{b}}$ & $815.59 \pm 57.169^{b}$ & $1.71 \pm 0.118^{\mathrm{b}}$ & $5.74 \pm 0.174^{\mathrm{b}}$ & $8.71 \pm 0.740^{c}$ \\
\hline $80 \%$ HPSC & $46.46 \pm 3.055^{c}$ & $719.40 \pm 55.969^{c}$ & $1.48 \pm 0.110^{c}$ & $6.54 \pm 0.226^{\mathrm{a}}$ & $7.57 \pm 1.190^{c}$ \\
\hline
\end{tabular}

Results are mean values of three parallel measurements in cakes baked in three replications. In a column, means with different letter are significantly different (p < 0.05). HPSC: Hachiya powder substituted cakes 


\section{Texture profile analysis of cakes}

The texture profile analysis results of control and Hachiya powder substituted cakes were given in Table 3 . The effect of substitution rate on textural properties of cakes was significant $(\mathrm{p}<0.05)$. Hardness and chewiness increased; springiness, cohesiveness and resilience decreased with Hachiya powder substitution with an exception in 20\% HPSC, showing decreased chewiness and comparable hardness with control cake. In contrast to our results, Hong \& Kim (2005) reported that inclusion of increasing rates of persimmon paste lead to decreased hardness and increased cohesiveness in comparison to control cake. This was probably due to high moisture content of the cakes (42.43$44.70 \%$ ) by inclusion of persimmon paste in stead of powder. In line with our findings, Choi et al. (2008) reported increasing hardness and cohesiveness values in $4-16 \%$ persimmon leaf powder included yellow layer cakes. On the other hand, all enriched cakes were statistically similar with control cake in terms of textural properties.

\subsection{Gliadin content and chemical composition of cakes}

Firstly, gluten analysis was carried out on randomly selected cakes (Control, 20\% HPSC and 80\% HPSC) to ensure that the cakes were gluten-free. All the cakes contained gliadin less than
20 ppm assuring gluten-free cakes according to the Turkish Food Codex Regulation "Rescript on Foods Suitable for Individuals with Gluten Intolerance” (Turkey, 2012).

Table 4 represents chemical composition of control and Hachiya powder substituted cakes. Moisture content of glutenfree persimmon powder substituted cakes varied between 21.37$24.48 \%$. The effect of persimmon powder substitution rate on the moisture content of cakes was statistically significant $(\mathrm{p}<0.05)$. It has been observed that the moisture content of the cakes increased as the persimmon substitution rate increased. This may be a result of high water binding ability of dietary fiber in persimmon powder. Another factor may be lower water vapor release from the cake as foaming ability is lower due to less sugar during baking. Ash content varied between 1.17-1.76\% in gluten-free cakes. Although ash content of persimmon fruit was not too high, high levels of inclusion lead to a significant increase in ash content of cakes $(\mathrm{p}<0.05)$. As the substitution rate increased, the ash content of the cakes also increased. Likewise ash content, persimmon powder substitution rate on the dietary fibre content of cakes was statistically significant $(\mathrm{p}<0.05)$. Dietary fibre of the persimmon powder substituted cakes increased with increasing fruit powder level and all samples were significantly different from each other. Gorinstein et al. (1999) conducted a comparative study on dietary fibre of persimmon and apple

Table 2. Interior color values of control and Hachiya powder substituted cakes

\begin{tabular}{|c|c|c|c|}
\hline Sample & $L^{*}$ & $a^{*}$ & $b^{*}$ \\
\hline Control & $71.85 \pm 0.650^{a}$ & $1.46 \pm 0.035^{\mathrm{a}}$ & $21.95 \pm 1.019^{\mathrm{ab}}$ \\
\hline $20 \%$ HPSC & $56.77 \pm 3.831^{\mathrm{b}}$ & $8.87 \pm 0.878^{\mathrm{b}}$ & $17.96 \pm 0.289^{c}$ \\
\hline $40 \%$ HPSC & $57.02 \pm 1.482^{\mathrm{b}}$ & $8.86 \pm 1.118^{\mathrm{b}}$ & $22.02 \pm 0.566^{\mathrm{ab}}$ \\
\hline $60 \%$ HPSC & $53.91 \pm 1.713^{\mathrm{b}}$ & $9.60 \pm 1.164^{\mathrm{b}}$ & $19.43 \pm 3.302^{\mathrm{bc}}$ \\
\hline $80 \%$ HPSC & $54.21 \pm 1.041^{\mathrm{b}}$ & $9.80 \pm 0.197^{b}$ & $23.26 \pm 0.821^{\mathrm{a}}$ \\
\hline
\end{tabular}

Results are mean values of six parallel readings in cakes baked in three replications. In a column, means with different letter are significantly different ( $\mathrm{p}<0.05$ ).

Table 3. Texture Profile Analysis of control and Hachiya powder substituted cakes

\begin{tabular}{|c|c|c|c|c|c|}
\hline \multirow{2}{*}{ Sample } & Hardness & \multirow{2}{*}{ Springiness } & \multirow{2}{*}{ Cohesiveness } & Chewiness & \multirow{2}{*}{ Resilience } \\
\hline & (g force) & & & (g force) & \\
\hline Control & $206.09 \pm 5.467^{\mathrm{d}}$ & $0.94 \pm 0.000^{\mathrm{a}}$ & $0.78 \pm 0.023^{\mathrm{a}}$ & $137.65 \pm 3.867^{\mathrm{d}}$ & $0.39 \pm 0.021^{\mathrm{a}}$ \\
\hline $20 \%$ HPSC & $190.4 \pm 1.200^{\mathrm{d}}$ & $0.84 \pm 0.015^{\mathrm{bc}}$ & $0.57 \pm 0.006^{\mathrm{b}}$ & $90.66 \pm 2.389^{\mathrm{e}}$ & $0.27 \pm 0.010^{\mathrm{b}}$ \\
\hline $40 \%$ HPSC & $274.10 \pm 20.614^{c}$ & $0.85 \pm 0.032^{\mathrm{b}}$ & $0.53 \pm 0.040^{b c}$ & $123.85 \pm 5.759^{c}$ & $0.20 \pm 0.006^{c}$ \\
\hline $60 \%$ HPSC & $370.84 \pm 62.763^{b}$ & $0.83 \pm 0.029^{b c}$ & $0.48 \pm 0.040^{\mathrm{cd}}$ & $148.83 \pm 3.768^{\mathrm{b}}$ & $0.24 \pm 0.010^{\mathrm{b}}$ \\
\hline $80 \%$ HPSC & $841.69 \pm 10.598^{a}$ & $0.79 \pm 0.020^{c}$ & $0.430 .037^{\mathrm{d}}$ & $280.74 \pm 2.295^{\mathrm{a}}$ & $0.22 \pm 0.004^{c}$ \\
\hline
\end{tabular}

Results are mean values of ten parallel measurements in cakes baked in three replications. In a column, means with different letter are significantly different ( $\mathrm{p}<0.05)$.

Table 4. Chemical composition of control and Hachiya powder substituted cakes

\begin{tabular}{|c|c|c|c|c|}
\hline \multirow{2}{*}{ Sample } & Moisture & Ash & Fat & Dietary Fibre \\
\hline & $(\%)$ & $\left(\% \mathrm{DB}^{\star}\right)$ & $(\% \mathrm{DB})$ & (\%DB) \\
\hline Control & $21.92 \pm 0.870^{\mathrm{b}}$ & $1.17 \pm 0.012^{\mathrm{e}}$ & $12.81 \pm 0.082$ & $0.07 \pm 0.014^{\mathrm{e}}$ \\
\hline $20 \%$ HPSC & $21.37 \pm 0.453^{\mathrm{b}}$ & $1.26 \pm 0.015^{\mathrm{d}}$ & $12.80 \pm 0.056$ & $0.56 \pm 0.031^{\mathrm{d}}$ \\
\hline $40 \%$ HPSC & $22.94 \pm 1.882^{\mathrm{ab}}$ & $1.28 \pm 0.006^{\mathrm{c}}$ & $12.83 \pm 0.065$ & $1.09 \pm 0.054^{\mathrm{c}}$ \\
\hline $60 \%$ HPSC & $23.99 \pm 0.214^{\mathrm{a}}$ & $1.36 \pm 0.006^{\mathrm{b}}$ & $12.70 \pm 0.146$ & $1.65 \pm 0.078^{b}$ \\
\hline $80 \%$ HPSC & $24.48 \pm 0.928^{\mathrm{a}}$ & $1.76 \pm 0.022^{\mathrm{a}}$ & $12.74 \pm 0.150$ & $2.21 \pm 0.082^{\mathrm{a}}$ \\
\hline
\end{tabular}

Results are mean values of three parallel measurements in cakes baked in three replications. In a column, means with different letter are significantly different $(\mathrm{p}<0.05) .{ }^{\star}$ dry base. 
and propounded that persimmon contained higher dietary fibre $(1.5 \%)$ in comparison to apple $(0.80 \%)$ in fresh fruits.

\subsection{Bioactivity of cakes}

Persimmon has different total phenolic compound depending on cultivars, parts, and solvents extraction (Suzuki et al., 2005). Phenolic compounds may be affected by a variety of factors including light, temperature, humidity, drought, and agronomic conditions factors, in different harvest regions (Abdallah et al., 2017). Persimmon has also been reported to be a good source of antioxidants and an important fruit in terms of bioactive components. Pu et al. (2013) examined the total phenolic substance, total flavanoid and total flavanol content of persimmon in their study. It has been reported that fruit has an antioxidant potential in food and pharmaceutical products. Comparative results of total phenolic content and antioxidant activity of control and hachiya powder substituted cakes were represented in Figure 1. Substitution of persimmon powder provided a significant increase in the bioactivity of the final cakes. Total phenolic content of persimmon substituted cakes increased up to $304.2 \%$ in comparison to control cake. All cakes were significantly different from each other $(\mathrm{p}<0.05)$. Similar to bioactivity, antiradical activity and ferric reducing antioxidant power of samples increased with the increase in persimmon powder concentration in the cake formulation. All the cakes were significantly different from control and each other in terms of DPPH and FRAP ( $\mathrm{p}<0.05)$. DPPH and FRAP of $80 \%$ HPSC increased by $264.3 \%$ and $384.4 \%$, respectively. In line with our findings, Abdallah et al. (2017) reported an increase in total phenolic content (220.53\%) and DPPH inhibition (53.81\%) of $33.3 \%$ persimmon pulp substituted cakes. Another study conducted on utilization of persimmon in ice cream (Karaman et al., 2014) also demonstrated the significant increase in bioactivity of enriched products.

\subsection{Mineral composition of cakes}

Table 5 represents the mineral composition of cake samples. Persimmon substition significantly affected mineral contents of cakes $(\mathrm{p}<0.05)$ except zinc content $(\mathrm{p}>0.05)$. Among all minerals, the most pronounced increase was observed in $\mathrm{K}$ content of the gluten-free cakes. It is not surprising as fruits are a good source of potassium. Mowat (1990) also stated that persimmon fruit (D. kaki L.) was a good source of calcium and potassium. Celik \& Ercişli (2008) found out in their study that potassium content of persimmon fruit (203 mg/100 g), Hachiya variety, was obviously higher than other minerals. Likewise, in the present study, K content increased visibly in enriched cakes.

\subsection{Sensory properties of cakes}

The consumers' expectations and attitudes are important for liking or disliking a food product (Meier-Dinkel et al., 2013). Food selection and consumption are affected by various factors such as marketing, psychological, and sensory related (Carneiro et al., 2006). There are several studies using several sensorial techniques to understand consumer perception and acceptance of foods. Schuch et al. (2019) investigated the effects of packaging attributes on consumer purchase intention. Torres et al. (2020) searched consumers' perception of Petit-Suisse cheese through the technique of completion task. Judacewski et al. (2019) and Vieira et al. (2020) used free word association method and free listing task, respectively, for dairy products. Sass et al. (2020) used social media as a tool to understand consumers' perception of eggs. In another study, da Costa et al. (2020) compared preferred attribute elicitation methodology and conventional descriptive analysis using probiotic yogurt added with prebiotic components. Silva et al. (2018) and used quantitative descriptive analysis (QDA) and temporal dominance of sensations in combination for sodium reduction in prato cheese. Mituniewicz-Małek et al. (2019) also conducted QDA in fermented goat milk beverages. QDA and temporal dominance

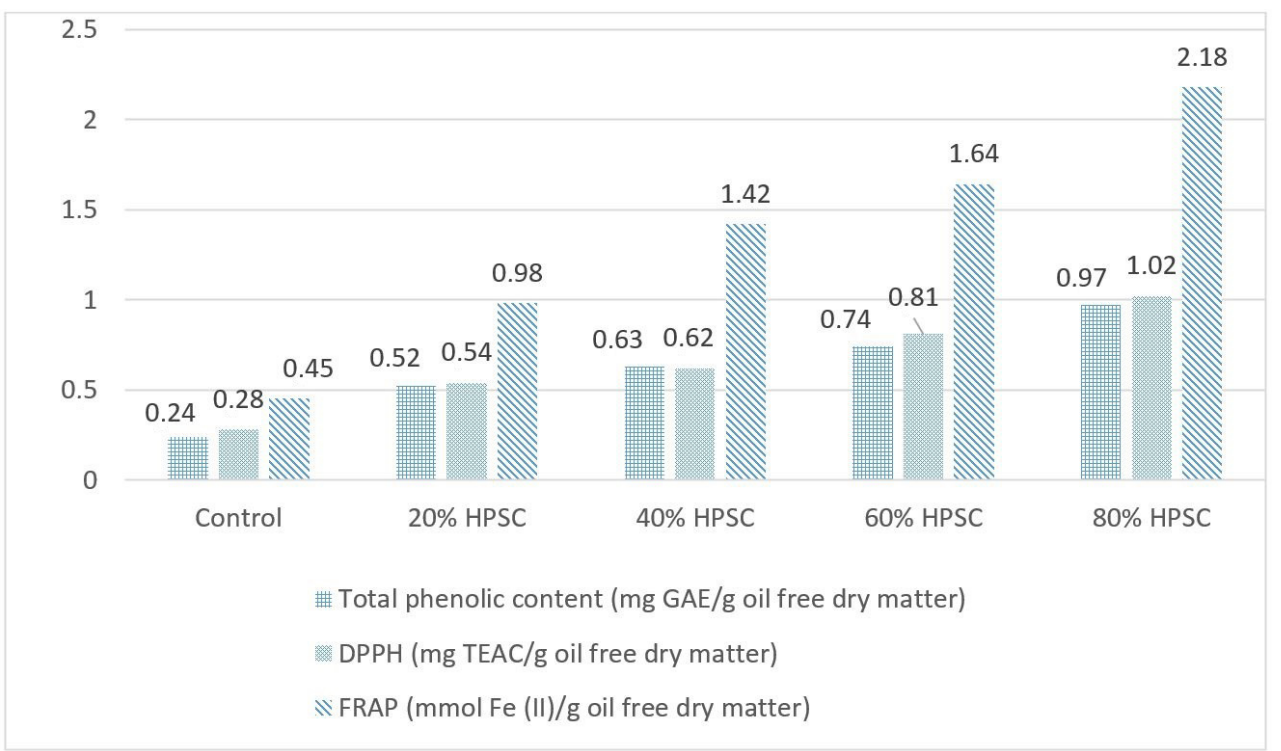

Figure 1. Comparative results of total phenolic content and antioxidant activity of control and Hachiya powder substituted cakes. 
Table 5. Mineral composition of control and Hachiya powder substituted cakes

\begin{tabular}{|c|c|c|c|c|c|c|}
\hline \multirow{2}{*}{ Sample } & $\mathrm{Fe}$ & $\mathrm{Ca}$ & $\mathrm{P}$ & $\mathrm{Zn}$ & $\mathrm{Mg}$ & $\mathrm{K}$ \\
\hline & $(\mathrm{mg} / \mathrm{kg})$ & $(\mathrm{mg} / \mathrm{kg})$ & $(\mathrm{mg} / \mathrm{kg})$ & $(\mathrm{mg} / \mathrm{kg})$ & $(\mathrm{mg} / \mathrm{kg})$ & $(\mathrm{mg} / \mathrm{kg})$ \\
\hline Control & $7.05 \pm 1.791^{\mathrm{c}}$ & $650.77 \pm 17.122^{\mathrm{dc}}$ & $3354.43 \pm 74.594^{\mathrm{b}}$ & $12.47 \pm 1.647$ & $179.81 \pm 17.881^{\mathrm{d}}$ & $1302.73 \pm 113.998^{c}$ \\
\hline $20 \%$ HPSC & $9.71 \pm 0.894^{\mathrm{bc}}$ & $631.24 \pm 25.867^{\mathrm{d}}$ & $3126.77 \pm 102.891^{\mathrm{dc}}$ & $13.69 \pm 0.593$ & $226.68 \pm 4.897^{c}$ & $2246.88 \pm 80.644^{\mathrm{b}}$ \\
\hline $40 \%$ HPSC & $11.99 \pm 0.888^{\mathrm{ab}}$ & $685.81 \pm 3.282^{\mathrm{bc}}$ & $2963.82 \pm 15.651^{\mathrm{d}}$ & $13.82 \pm 0.323$ & $283.02 \pm 1.731^{\mathrm{a}}$ & $2134.30 \pm 3.667^{\mathrm{b}}$ \\
\hline $60 \%$ HPSC & $10.95 \pm 0.528^{\mathrm{ab}}$ & $795.10 \pm 6.939^{\mathrm{a}}$ & $3584.36 \pm 97.497^{a}$ & $13.14 \pm 1.107$ & $274.35 \pm 11.319^{\mathrm{ab}}$ & $2263.53 \pm 8.739^{\mathrm{b}}$ \\
\hline $80 \%$ HPSC & $13.11 \pm 1.181^{\mathrm{a}}$ & $704.99 \pm 9.484^{\mathrm{ab}}$ & $3223.81 \pm 36.726^{b c}$ & $12.24 \pm 2.204$ & $254.89 \pm 1.209^{\mathrm{b}}$ & $2473.09 \pm 59.647^{\mathrm{a}}$ \\
\hline
\end{tabular}
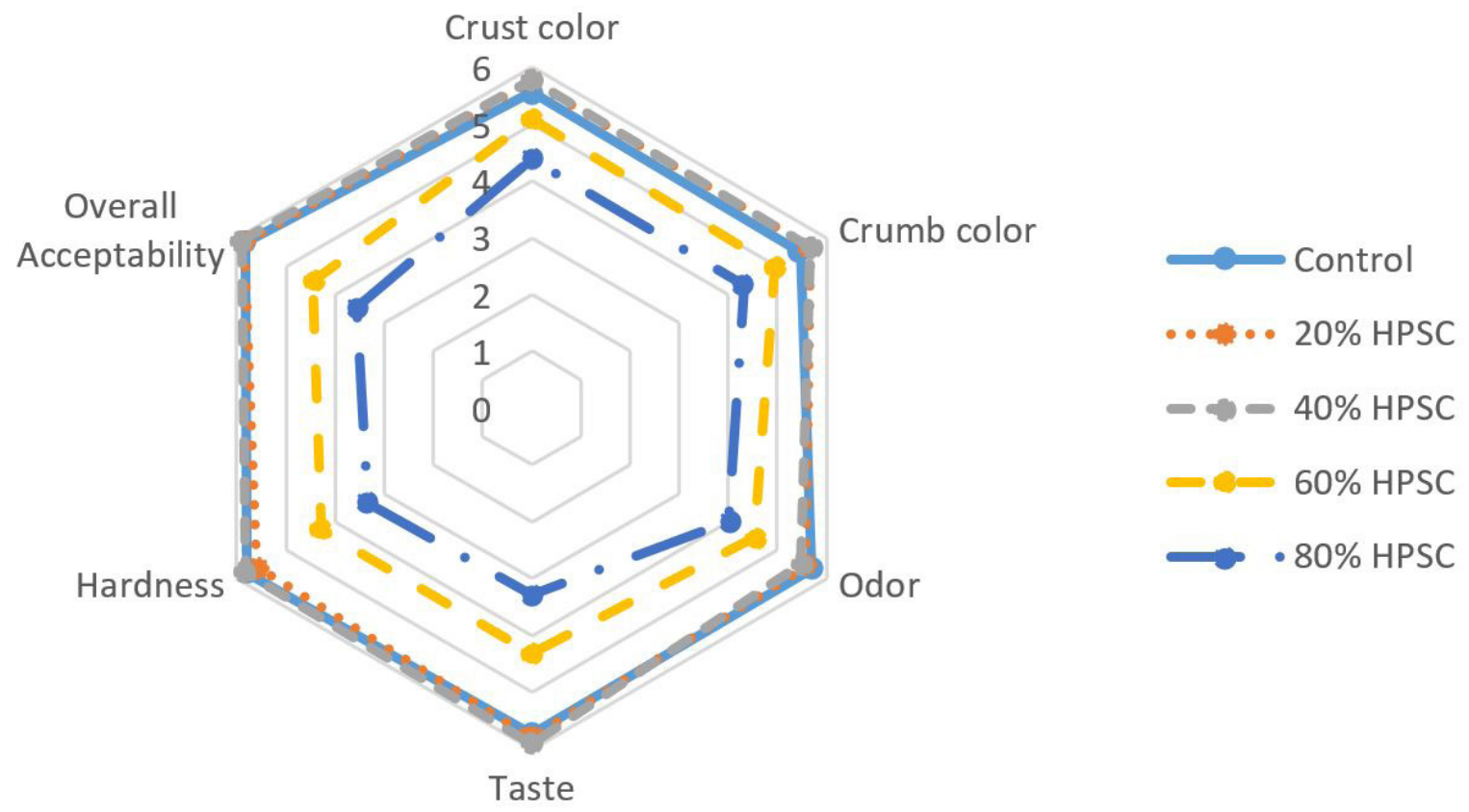

Figure 2. Sensory properties of control and Hachiya powder substituted cakes.

of sensations can provide complementary information about the sensory interactions in foods (Devezeaux de Lavergne et al., 2015; Braghieri et al., 2016). As can be seen, there are several sensory methods that is on rise in the last years. QDA is advantageous as it allows more attributes to be investigated for a complete sensory profile of the product (Silva et al., 2018). On the other hand, hedonic scale is still commonly used in many studies and provides reliable data on liking or disliking a food product. In the present study, cakes were sensorially analysed in terms of crumb and crust color, odor, taste, hardness and overall acceptability on a 7 point hedonic scale as seen in Figure 2. Persimmon powder substitution enabled sensorially acceptable cakes with enriched content. Substitution levels up to $40 \%$ lead to cakes statistically similar to control ( $p>0.05) .60 \%$ and $80 \%$ HPSC had deteriorated sensorial properties. Similarly, Abdallah et al. (2017) reported that inclusion of $50-83.3 \%$ persimmon puree in wheat flour cupcakes resulted in decreased sensorial scores in comparison to control whereas $33.3 \%$ persimmon puree replacement lead to an increase in taste, flavor, color, texture and overall acceptability scores. Hong \& Kim (2005) reported higher overall acceptability scores in rice cakes enriched with persimmon paste in comparison to control. Another study on utilization of persimmon leaf powder in yellow cake formulation (Choi et al., 2008) showed that $8 \%$ persimmon leaf powder gave cakes with higher overall acceptability scores than control. However, enriched cakes in that study were statistically similar with control cake. Persimmon was also formerly used in dairy products like ice cream and yogurt. Karaman et al. (2014) reported comparable overall acceptability in ice creams enriched with $24 \%$ persimmon puree. Arslan \& Bayrakci (2016) conducted a comparative study on utilization of persimmon puree and marmalade at concentrations of $10 \%$ and $12 \%$ in yogurt production and propounded use of marmalade due to overall acceptability scores similar with control yogurt. Results of the present and mentioned studies demonstrates that persimmon is a suitable food ingredient due to its sensorially acceptable flavor. Analyses on sensory properties can be supported by quantitative descriptive analysis in future studies for sensory profiling of persimmon substituted cakes.

\section{Conclusions}

Persimmon is a promising food ingredient due to high bioactivity, minor compounds, dietary fibre and sugar content. Gluten-free foods need to be enriched with ingredients that have 
nutritious content. Enriched gluten-free cakes with increased $\mathrm{K}$, antioxidant activity, total phenolic content and favorable sensorial and physical properties were achieved by 20 and $40 \%$ persimmon powder substitution. Gluten-free cakes with persimmon powder can be a good solution to contribute to daily and social life of celiac people and also to fill the gap in gluten-free food market. Further studies can be conducted to develop various bakery products with persimmon inclusion. Determination of bioaccessability of minor and major components of enriched cakes are also of value.

\section{Acknowledgements}

This study was finally supported by Manisa Celal Bayar University, Scientific Research Project Coordination Unit (Grant Number 2018-188).

\section{References}

Abdallah, D. A., El-Mageed, A., Siliha, H. A., \& Rabie, M. A. (2017). Physicochemical characteristics of persmmon puree and its utilization in cupcake. Zagazig Journal of Agricultural Research, 44(6), 26292640. http://dx.doi.org/10.21608/zjar.2017.51370.

Aksoylu, Z., Çağindi, Ö., \& Köse, E. (2015). Effects of blueberry, grape seed powder and poppy seed incorporation on physicochemical and sensory properties of biscuit. Journal of Food Quality, 38(3), 164-174. http://dx.doi.org/10.1111/jfq.12133.

Al-Sayed, H. M., \& Ahmed, A. R. (2013). Utilization of watermelon rinds and sharlyn melon peels as a natural source of dietary fiber and antioxidants in cake. Annals of Agricultural Science, 58(1), 8395. http://dx.doi.org/10.1016/j.aoas.2013.01.012.

American Association of Cereal Chemists - AACC. (2010). AACC method 38-50.01: immunochemical determination of gluten in corn flour and corn-based products by Sandwich ELISA: approved methods of analysis (11th ed.). St. Paul: AACC International.

Arslan, S., \& Bayrakci, S. (2016). Physicochemical, functional, and sensory properties of yogurts containing persimmon. Turkish Journal of Agriculture and Forestry, 40(1), 68-74. http://dx.doi.org/10.3906/ tar-1406-150.

Association of Official Analytical Chemists - AOAC. (2000). Association of Official Analytical Chemist Official method 934.01 Loss on drying (moisture) at $95-100^{\circ} \mathrm{C}$ for feed, 923.03 Ash of flour. Rockville: AOAC International.

Association of Official Analytical Chemists - AOAC. (2003). Association of Official Analytical Chemist Official method 991.43 total, soluble, and insoluble dietary fiber in foods. In W. Horwithz (Ed.), Official methods of analysis of the AOAC international rev. 2 (17th ed). Gaithersburg: AOAC International.

Braghieri, A., Piazzolla, N., Galgano, F., Condelli, N., De Rosa, G., \& Napolitano, F. (2016). Effect of preservative addition on sensory and dynamic profile of Lucanian dry-sausages as assessed by quantitative descriptive analysis and temporal dominance of sensations. Meat Science, 122, 68-75. http://dx.doi.org/10.1016/j.meatsci.2016.07.020. PMid:27486959.

Brand-Williams, W., Cuvelier, M. E., \& Berset, C. (1995). Use of a free radical method to evaluate antioxidant activity. LebensmittelWissenschaft + Technologie, 28(1), 25-30. http://dx.doi.org/10.1016/ S0023-6438(95)80008-5.

Carneiro, J. D. S., Silva, C. H. O., \& Minim, V. P. R. (2006). Análise conjunta de fatores. In: V. P. R. Minim (Ed.), Análise sensorial: estudo com consumidores (pp. 127-172). Viçosa: UFV.
Celik, A., \& Ercişli, S. (2008). Persimmon cv. Hachiya (Diospyros kaki Thunb.) fruit: some physical, chemical and nutritional properties. International Journal of Food Sciences and Nutrition, 59(7-8), 599606. http://dx.doi.org/10.1080/09637480701538221. PMid:19382348.

Choi, G. Y., Bae, J. H., \& Han, G. J. (2008). Quality characteristics of yellow layer cake containing varying amounts of persimmon leaf powder. Journal of the East Asian Society of Dietary Life, 18(4), 531-538.

Costa, G. M., Paula, M. M., Costa, G. N., Esmerino, E. A., Silva, R., Freitas, M. Q., Barão, C. E., Cruz, A. G., \& Pimentel, T. C. (2020). Preferred attribute elicitation methodology compared to conventional descriptive analysis: a study using probiotic yogurt sweetened with xylitol and added with prebiotic components. Journal of Sensory Studies, 35(6), e12602. http://dx.doi.org/10.1111/joss.12602.

Devezeaux de Lavergne, M., Van Delft, M., Van de Velde, F., Van Boekel, M. A. J. S., \& Stieger, M. (2015). Dynamic texture perception and oral processing of semi-solid food gels: part 1: comparison between QDA, progressive profiling and TDS. Food Hydrocolloids, 43, 207217. http://dx.doi.org/10.1016/j.foodhyd.2014.05.020.

Doymaz, İ. (2012). Evaluation of some thin-layer drying models of persimmon slices (Diospyros kaki L.). Energy Conversion and Management, 56, 199-205. http://dx.doi.org/10.1016/j.enconman.2011.11.027.

Feng, N., Tang, S., Zhou, M., Lv, Z., Chen, Y., Li, P., \& Wu, Q. (2019). Optimizing the texture and retrogradation properties of Niangao (Rice Cake) made with naturally fermented rice flour. Food Science and Technology, 39(4), 810-817. http://dx.doi.org/10.1590/fst.02618.

Geisslitz, S., Wieser, H., Scherf, K. A., \& Koehler, P. (2018). Gluten protein composition and aggregation properties as predictors for bread volume of common wheat, spelt, durum wheat, emmer and einkorn. Journal of Cereal Science, 83, 204-212. http://dx.doi. org/10.1016/j.jcs.2018.08.012.

Giordani, E., Doumett, S., Nin, S., \& Del Bubba, M. (2011). Selected primary and secondary metabolites in fresh persimmon (Diospyros kaki thunb.): a review of analytical methods and current knowledge of fruit composition and health benefits. Food Research International, 44(7), 1752-1767. http://dx.doi.org/10.1016/j.foodres.2011.01.036.

Gorinstein, S., Zemser, M., Haruenkit, R., Chuthakorn, R., Grauer, F., Martin-Belloso, O., \& Trakhtenberg, S. (1999). Comparative content of total polyphenols and dietary fiber in tropical fruits and persimmon. The Journal of Nutritional Biochemistry, 10(6), 367-371. http://dx.doi.org/10.1016/S0955-2863(99)00017-0. PMid:15539312.

Gu, H., Li, C., Xu, Y., Hu, W., Chen, M., \& Wan, Q. (2008). Structural features and antioxidant activity of tannin from persimmon pulp. Food Research International, 41(2), 208-217. http://dx.doi.org/10.1016/j. foodres.2007.11.011.

Gularte, M. A., De la Hera, E., Gómez, M., \& Rosell, C. M. (2012). Effect of different fibers on batter and gluten-free layer cake properties. Lebensmittel-Wissenschaft + Technologie, 48(2), 209-214. http:// dx.doi.org/10.1016/j.lwt.2012.03.015.

Güven, A., \& Gürsul, I. (2014). Bitki doku kültürlerinde sekonder metabolit sentezi. Gida, 39(5), 299-306.

Ho, L. H., Abdul Aziz, N. A., \& Azahari, B. (2013). Physico-chemical characteristics and sensory evaluation of wheat bread partially substituted with banana (Musa acuminata x Balbisiana cv. awak) pseudo-stem flour. Food Chemistry, 139(1-4), 532-539. http://dx.doi. org/10.1016/j.foodchem.2013.01.039. PMid:23561142.

Hong, J. S., \& Kim, M. (2005). Quality characteristics of Sulgiduck by the addition of astringency persimmon paste. Korean Journal of Food and Cookery Science, 21(3), 360-370.

Ittah, Y. (1993). Sugar content changes in persimmon fruits (Diospyros kaki $\mathrm{L}$.) during artificial ripening with $\mathrm{CO}_{2}$ : a possible connection to deastringency mechanisms. Food Chemistry, 48(1), 25-29. http:// dx.doi.org/10.1016/0308-8146(93)90216-3. 
Judacewski, P., Los, P. R., Lima, L. S., Alberti, A., Zielinski, A. A. F., \& Nogueira, A. (2019). Perceptions of Brazilian consumers regarding white mould surface-ripened cheese using free word association. International Journal of Dairy Technology, 72(4), 585-590. http:// dx.doi.org/10.1111/1471-0307.12649.

Karaman, S., Toker, Ö. S., Yüksel, F., Çam, M., Kayacier, A., \& Dogan, M. (2014). Physicochemical, bioactive, and sensory properties of persimmon-based ice cream: Technique for order preference by similarity to ideal solution to determine optimum concentration. Journal of Dairy Science, 97(1), 97-110. http://dx.doi.org/10.3168/ jds.2013-7111. PMid:24268400.

Karhan, M., Artık, N., \& Özdemir, F. (2003). Trabzon hurmasının (Diospyros kaki L.) olgunlaşma sürecinde HPLC ile belirlenen majör fenolik bileşik, majör karotenoid bileşik ve L-askorbik asit kompozisyonunun değişimi. Gida, 28(4), 349-353.

Kim, C. S., \& Walker, C. E. (1992). Interactions between starches, sugars and emulsifiers in high-ratio cake model systems. Cereal Chemistry, 69(2), 206-212.

Kim, S. S., \& Setser, C. S. (1992). Wheat starch gelatinization in the presence of polydextrose or hydrolyzed barley $\beta$-glucan. Cereal Chemistry, 69(4), 447-451.

Kırbaş, Z., Kumcuoglu, S., \& Tavman, S. (2019). Effects of apple, orange and carrot pomace powders on gluten-free batter rheology and cake properties. Journal of Food Science and Technology, 56(2), 914-926. http://dx.doi.org/10.1007/s13197-018-03554-z. PMid:30906049.

Lazaridou, A., Duta, D., Papageorgiou, M., Belc, N., \& Biliaderis, C. G. (2007). Effects of hydrocolloids on dough rheology and bread quality parameters in gluten-free formulations. Journal of Food Engineering, 79(3), 1033-1047. http://dx.doi.org/10.1016/j.jfoodeng.2006.03.032.

Liu, H. Y., Qiu, N. X., Ding, H. H., \& Yao, R. Q. (2008). Polyphenols contents and antioxidant capacity of Chinese herbals suitable for medical or food uses. Food Research International, 41(4), 363-370. http://dx.doi.org/10.1016/j.foodres.2007.12.012.

Meier-Dinkel, L., Trautmann, J., Frieden, L., Tholen, E., Knorr, C., Sharifi, A. R., Bücking, M., Wicke, M., \& Mörlein, D. (2013). Consumer perception of boar meat as affected by labelling information, malodorous compounds and sensitivity to androstenone. Meat Science, 93(2), 248-256. http://dx.doi.org/10.1016/j.meatsci.2012.09.002. PMid:23036943.

Mituniewicz-Małek, A., Zielińska, D., \& Ziarno, M. (2019). Probiotic monocultures in fermented goat milk beverages-sensory quality of final product. International Journal of Dairy Technology, 72(2), 240-247. http://dx.doi.org/10.1111/1471-0307.12576.

Mowat, A. (1990). The world scene: production and marketing. In: R. J. Collins (Ed.), Charting the Future: Proceedings of the First National Non-Astringent Persimmon Industry Workshop (pp. 37-51). Brisbane, Australia: Gatton College, The University of Queensland.

Nordic Committee on Food Analysis - NMKL. (1998). NMKL Method No. 161: metals: determination by atomic adsorption spectrophotometry after wet digestion in microwave oven (p. 8). Norway: Nordic Committee on Food Analysis.

Paton, D., Larocque, G. M., \& Holme, J. (1981). Development of cake structure: Influence of ingredients on the measurement of cohesive force during baking. Cereal Chemistry, 58(6), 527-529.

Piretti, M. V. (1991). Polyphenol constituents of the Diospyros kaki fruit: a review. Fitoterapia, 1, 3-13.

Pu, F., Ren, X., \& Zhang, X. (2013). Phenolic compounds and antioxidant activity in fruits of six Diospyros kaki genotypes. European Food Research and Technology, 237(6), 923-932. http://dx.doi.org/10.1007/ s00217-013-2065-z.
Sabanis, D., Lebesi, D., \& Tzia, C. (2009). Effect of dietary fibre enrichment on selected properties of gluten-free bread. Lebensmittel-Wissenschaft + Technologie, 42(8), 1380-1389. http://dx.doi.org/10.1016/j. lwt.2009.03.010.

Sass, C. A. B., Pimentel, T. C., Aleixo, M. G. B., Dantas, T. M., Oliveira, F. L. O., Freitas, M. Q., Cruz, A. G., \& Esmerino, E. A. (2020). Exploring social media data to understand consumers' perception of eggs: a multilingual study using Twitter. Journal of Sensory Studies, 35(6), e12607. http://dx.doi.org/10.1111/joss.12607.

Savlak, N., Türker, B., \& Yeşilkanat, N. (2016). Effects of particle size distribution on some physical, chemical and functional properties of unripe banana flour. Food Chemistry, 213, 180-186. http://dx.doi. org/10.1016/j.foodchem.2016.06.064. PMid:27451170.

Schuch, A. F., Silva, A. C. D., Kalschne, D. L., Silva-Buzanello, R. A. D., Corso, M. P., \& Canan, C. (2019). Chicken nuggets packaging attributes impact on consumer purchase intention. Food Science and Technology, 39(Suppl. 1), 152-158. http://dx.doi.org/10.1590/fst.41317.

Silva, H. L. A., Balthazar, C. F., Silva, R., Vieira, A. H., Costa, R. G. B., Esmerino, E. A., Freitas, M. Q., \& Cruz, A. G. (2018). Sodium reduction and flavor enhancer addition in probiotic prato cheese: contributions of quantitative descriptive analysis and temporal dominance of sensations for sensory profiling. Journal of Dairy Science, 101(10), 8837-8846. http://dx.doi.org/10.3168/jds.201814819. PMid:30077456.

Singleton, V. L., \& Rossi, J. A. (1965). Colorimetry of total phenolics with phosphomolybdicphosphotungstic acid reagents. American Journal of Enology and Viticulture, 16, 144-158.

Statistical Analytical Systems - SAS. (2001). SAS users guide: statistics. Cary, NC: SAS Institute Inc.

Suzuki, T., Someya, S., Hu, F., \& Tanokura, M. (2005). Comparative study of catechin compositions in five Japanese persimmons. Food Chemistry, 93(1), 149-152. http://dx.doi.org/10.1016/j.foodchem.2004.10.017.

Torres, F. R., Silva, H. L. A. D., Cutrim, C. S., \& Cortez, M. A. S. (2020). Consumer perception of Petit-Suisse cheese: identifying market opportunities for the Brazilian dairy industry. Food Science and Technology, 40(Suppl. 2), 653-660. http://dx.doi.org/10.1590/fst.38319.

Türker, B., Savlak, N., \& Kaşıkcı, M. B. (2016). Effect of green banana peel flour substitution on physical characteristics of gluten-free cakes. Current Research in Nutrition and Food Science Journal, 4, 197-204. http://dx.doi.org/10.12944/CRNFSJ.4.Special-Issue-October.25.

Turkey. (2012). Turkish Food Codex Regulation "Rescript on Foods Suitable for Individuals with Gluten Intolerance". Rescript No: 2012/4, RG: 28163. Official Gazette.

Veberic, R., Jurhar, J., Mikulic-Petkovsek, M., Stampar, F., \& Schmitzer, V. (2010). Comparative study of primary and secondary metabolites in 11 cultivars of persimmon fruit (Diospyros kaki L.). Food Chemistry, 119(2), 477-483. http://dx.doi.org/10.1016/j.foodchem.2009.06.044.

Vieira, A. H., Balthazar, C. F., Rocha, R. S., Silva, R., Guimarães, J. T., Pagani, M. M., Pimentel, T. C., Esmerino, E. A., Silva, M. C., Tonon, R. V., Freitas, M. Q., \& Cruz, A. G. (2020). The free listing task for describing the sensory profiling of dairy foods: a case study with microfiltered goat whey orange juice beverage. Journal of Sensory Studies, 35(5), e12594. http://dx.doi.org/10.1111/joss.12594.

Wang, Y., Zhang, M., \& Mujumdar, A. S. (2012). Influence of green banana flour substitution for cassava starch on the nutrition, color, texture and sensory quality in two types of snacks. LebensmittelWissenschaft + Technologie, 47(1), 175-182. http://dx.doi.org/10.1016/j. lwt.2011.12.011. 